\title{
HUBUNGAN LUARAN SUBJECTIVE GLOBAL ASSESSMENT (SGA) DENGAN DERAJAT KEPARAHAN STROKE
}

\author{
ASSOCIATION BETWEEN SUBJECTIVE GLOBAL ASSESSMENT (SGA) \\ OUTCOMES AND STROKE SEVERITY
}

Lisda Amalia, * Fadila Arsanti, ** Ginna Megawati***

\section{ABSTRACT}

Introduction: Stroke is a cerebrovascular disease caused by the sudden death of brain cells. Nutrition plays an important role in stroke. Inadequate intake of nutrients affects severity of stroke. Subjective Global Assessment (SGA) can be used to assess the nutritional status of stroke patients, while severity of stroke is known by assessing neurological deficits based on the National Institute of Health Stroke Scale (NIHSS).

Aims: To determine the association between SGA outcomes and stroke severity based on NIHSS.

Methods: A cross-sectional study with consecutive sampling in stroke patients who were treated in the neurological ward of Dr. Hasan Sadikin Hospital, Bandung between August-October 2018. Subjective Global Assessment and NIHSS were assessed. Alternative statistical test Fisher's exact test was used to see the relationship between these two variables.

Results: Among 40 patients, $57.5 \%$ were female, $37.5 \%$ had a stroke at the age of 50-59 years, the main risk factor of stroke was hypertension. Recurrence stroke were more common (52.5\%), with most of them were ischemic stroke (60\%). The most common neurological deficit was hemiplegia. Subjects with malnutrition (SGA C) were 40\%. Fifty percent patients had moderate neurological deficits based on NIHSS. The association between variables by Fisher's exact test was 0.008.

Discussion: There was a significant association between SGA outcomes and stroke severity based on NIHSS.

Keywords: NIHSS, nutritional status, SGA, stroke severity

\section{ABSTRAK}

Pendahuluan: Stroke merupakan penyakit serebrovaskular yang disebabkan adanya kematian mendadak sel otak. Nutrisi berperan penting pada stroke. Asupan nutrisi yang tidak adekuat berpengaruh terhadap derajat keparahan stroke. Subjective Global Assessment (SGA) dapat menilai status gizi pasien stroke, sedangkan derajat keparahan stroke diketahui dengan menilai defisit neurologis berdasarkan National Institute of Health Stroke Scale (NIHSS).

Tujuan: Mengetahui hubungan antara luaran SGA dengan derajat keparahan stroke berdasarkan NIHSS.

Metode: Analisis potong lintang dengan consecutive sampling pada pasien stroke yang dirawat di bangsal Neurologi RSUP Dr. Hasan Sadikin, Bandung bulan Agustus-Oktober tahun 2018. Variabel yang dinilai pada penelitian adalah SGA dan NIHSS. Uji alternative Fisher's exact test digunakan untuk melihat hubungan antar variabel.

Hasil: Dari 40 subjek penelitian sebanyak 57,5\% berjenis kelamin perempuan, 37,5\% mengalami stroke pada usia 50-59 tahun, memiliki faktor risiko utama hipertensi. Stroke berulang lebih banyak terjadi (52,5\%), jenis stroke terbanyak adalah iskemik (60\%). Defisit neurologis terbanyak yaitu hemiplegia. Subjek dengan gizi buruk (SGA C) sebanyak $40 \%$. Derajat keparahan NIHSS dengan defisit neurologis sedang yaitu 50\%. Hubungan antar kedua variabel, uji alternative Fisher's exact test memperoleh hasil 0,008. NIHSS.

Diskusi: Terdapat hubungan yang bermakna antara luaran SGA dengan derajat keparahan stroke berdasarkan

Kata kunci: Derajat keparahan stroke, NIHSS, SGA, status gizi

*Departemen Neurologi FK Universitas Padjadjaran, Bandung; **FK Universitas Padjadjaran, Bandung; ***Departemen Kesehatan Masyarakat FK Universitas Padjadjaran, Bandung. Korespondensi: dr.lisda@gmail.com.

\section{PENDAHULUAN}

Stroke merupakan penyakit serebrovaskular yang disebabkan kematian mendadak sel otak karena kurangnya suplai oksigen pada aliran darah otak. Stroke terjadi karena sumbatan pada lumen pembuluh darah akibat embolus atau trombus, kerusakan pembuluh arteri di otak, perubahan permeabilitas dinding pembuluh darah, peningkatan viskositas atau perubahan pada kualitas darah yang mengalir melalui pembuluh darah otak. Penyebab umum terjadinya kerusakan tersebut dapat disebabkan oleh aterosklerosis, arteriosklerotik hipertensif, arteritis yang menyebabkan stroke iskemik, dan dilatasi aneurisme, serta perkembangan malformasi pembuluh 
darah yang menyebabkan stroke perdarahan. ${ }^{1}$

Stroke adalah penyakit penyebab kematian kedua dan disabilitas ketiga di dunia menurut World Health Organization (WHO). ${ }^{2}$ Kementerian Kesehatan Republik Indonesia memaparkan bahwa penyakit stroke merupakan penyebab kematian pertama di rumah sakit pemerintah. Rumah Sakit Umum Pusat (RSUP) Dr. Hasan Sadikin, Bandung merupakan rumah sakit rujukan nasional yang memiliki lebih dari 500 kasus stroke pertahunnya. ${ }^{3}$

Nutrisi berperan dalam memengaruhi penyakit stroke, baik sebelum maupun setelah serangan stroke akut. Asupan nutrisi yang tidak adekuat dapat menjadi faktor risiko luaran klinis yang buruk sehingga berpengaruh terhadap derajat keparahannya. Penelitian sebelumnya secara signifikan menunjukkan bahwa pasien stroke banyak yang memiliki kondisi nutrisi tidak baik. Malnutrisi bisa terjadi pada saat awal perawatan, selama masa perawatan, hingga pasien menjalani rawat jalan serta berpengaruh terhadap lama waktu rawat. ${ }^{4}$ Penelitian di Belanda membuktikan bahwa pasien yang datang tanpa riwayat malnutrisi sebanyak $26 \%$ mengalami malnutrisi setelah dirawat. ${ }^{5}$ Malnutrisi berpengaruh terhadap luaran klinis, terjadinya komplikasi, gangguan fungsi imunologi, dan meningkatkan risiko mortalitas. ${ }^{6}$

Penelitian deskriptif tahun 2014 yang dilakukan pada 26 pasien stroke di RSUP Dr. Hasan Sadikin, Bandung menunjukkan hasil yang serupa, didapatkan $69,22 \%$ pasien mengalami malnutrisi sedang, namun tidak diketahui hubungan antara luaran status gizi dengan luaran klinisnya. ${ }^{7}$ Data mengenai hubungan ini penting untuk diteliti sebagai masukan intervensi gizi sehingga diharapkan memperbaiki prognosis pasien stroke.

Subjective Global Assessment (SGA) merupakan salah satu metode penilaian untuk mengetahui serta memantau gambaran status gizi pada pasien stroke. ${ }^{8}$ Salah satu metode yang digunakan untuk membantu mengetahui luaran klinis pasien stroke adalah National Institute of Health Stroke Scale (NIHSS). Metode pemeriksaan ini juga dapat menilai derajat keparahan stroke yang dilihat dari defisit neurologisnya. ${ }^{9}$
Berdasarkan uraian di atas, penelitian ini bertujuan untuk mengetahui hubungan luaran SGA dengan derajat keparahan stroke berdasarkan NIHSS pada pasien stroke yang dirawat di bangsal Neurologi RSUP Dr. Hasan Sadikin, Bandung pada tahun 2018.

\section{METODE}

Penelitian dilakukan dengan metode analisis potong lintang terhadap pasien stroke yang dirawat di bangsal Neurologi RSUP Dr. Hasan Sadikin, Bandung dari bulan Agustus sampai dengan Oktober tahun 2018. Sampel penelitian ditentukan dengan consecutive sampling. Data derajat keparahan dengan NIHSS merupakan data primer dan data luaran SGA adalah data sekunder dari rekam medis. Kriteria inklusi yaitu pasien stroke yang dirawat di bangsal Neurologi RSUP Dr. Hasan Sadikin, Bandung tanpa adanya riwayat malnutrisi sebelum stroke. Kriteria eksklusi yaitu pasien stroke yang mengalami demensia, tidak kooperatif selama pengambilan data dan tidak memiliki status SGA lengkap pada rekam medis.

Penilaian SGA meliputi nilai subjektif berdasarkan 5 komponen riwayat medis pasien yaitu berat badan, perubahan asupan makanan, gejala gastrointestinal, kapasitas fungsional dan stres metabolik karena suatu penyakit, serta pemeriksaan fisik meliputi 3 komponen yaitu penurunan massa otot, penurunan lemak subkutan, serta adanya edema dan asites yang berkaitan dengan faktor nutrisi. Luaran SGA dikategorikan menjadi tiga kategori yaitu pasien dengan gizi baik (SGA A), gizi kurang (SGA B), dan gizi buruk (SGA C). ${ }^{8}$ Penilaian NIHSS terdiri dari 11 item pemeriksaan, yang meliputi derajat kesadaran, gerakan mata conjugate horizontal, lapang pandang, paresis pada wajah, kekuatan motorik, ataksia, sensorik, bahasa, disartria, dan neglect. Hasil skor dari penilaian NIHSS berkisar antara $0-42$. Selanjutnya dikategorikan menjadi ringan $(<5)$, sedang (6-14), berat (15-24) dan sangat berat $(>25) .{ }^{10}$ Pada penelitian ini subjek dikategorikan menjadi derajat keparahan tidak berat $(0-14)$ dan berat $(>15) .{ }^{11}$ Pengambilan data dilakukan setelah pasien terdiagnosis stroke, selanjutnya SGA dinilai saat awal perawatan, dan selama masa perawatan 
pemeriksaan NIHSS dilakukan untuk menilai derajat keparahannya. Uji statistik Chi-square atau Fisher's exact test digunakan untuk melihat hubungan antara kedua variabel. Etik penelitian diperoleh dari Komite Etik Penelitian Universitas Padjadjaran.

\section{HASIL}

Selama periode penelitian, dari 120 pasien stroke didapatkan 40 subjek penelitian yang memenuhi kriteria inklusi. Tabel 1 menggambarkan bahwa sebagian besar subjek penelitian berjenis kelamin perempuan, yaitu 23 orang (57,5\%). Sebanyak 15 orang $(37,5 \%)$ mengalami stroke pada usia 50-59 tahun. Pada penelitian ini faktor risiko terbanyak adalah hipertensi berjumlah 36 orang. Satu pasien dapat memiliki lebih dari satu faktor risiko stroke.

\begin{tabular}{lc} 
Tabel 1. Karakteristik Subjek Penelitian $(\mathbf{n}=\mathbf{4 0})$ \\
\hline Variabel & $\mathbf{n}(\mathbf{\%})$ \\
\hline Jenis Kelamin & \\
- Laki-laki & $23(42,5)$ \\
- Perempuan & \\
Usia (Tahun) & $0(0)$ \\
- $<40$ & $8(20)$ \\
- $40-49$ & $15(37,5)$ \\
- $50-59$ & $7(17,5)$ \\
- $60-69$ & $10(25)$ \\
- $>70$ & \\
Faktor Risiko* & 36 \\
- Hipertensi & 3 \\
- Diabetes melitus & 5 \\
- Dislipidemia & 4 \\
- Rokok & \\
\hline
\end{tabular}

*Satu pasien bisa memiliki lebih dari satu faktor risiko.

Pada penelitian ini stroke berulang lebih sering terjadi sebanyak 21 orang (52,5\%), dengan jenis stroke terbanyak adalah iskemik yang berjumlah 24 orang (60\%) (Tabel 2). Kondisi defisit neurologis yang paling banyak terjadi adalah hemiplegia sebanyak 38 orang. Pasien dengan gizi baik (SGA A) 9 orang (22,5\%), gizi kurang (SGA B) 15 orang $(37,5 \%)$ dan terbanyak 16 orang $(40 \%)$ gizi buruk (SGA C). Derajat keparahan berdasarkan NIHSS yang terbanyak adalah defisit neurologis sedang 20 orang (50\%), defisit neurologis ringan 12 orang $(30 \%)$ dan defisit neurologis berat 8 orang $(20 \%)$.
Tabel 2. Karakteristik Klinis Subjek Penelitian $(n=40)$

\begin{tabular}{lc}
\hline Variabel & n (\%) \\
\hline Awitan Stroke & \\
- Pertama & $19(47,5)$ \\
- Berulang & $21(52,5)$ \\
Jenis Stroke & \\
- Perdarahan & $16(40)$ \\
- Iskemik & $24(60)$ \\
Defisit Neurologis** & \\
- Disfagia & 18 \\
- Penurunan kesadaran & 17 \\
- Afasia & 23 \\
- Disartria & 11 \\
- Hemiplegia & 38 \\
Subjective Global Assessment & \\
- SGA A (gizi baik) & \\
- SGA B (gizi kurang) & $9(22,5)$ \\
National Institute of Health Stroke Scale & $15(37,5)$ \\
- Ringan & $12(30)$ \\
- Sedang & $20(50)$ \\
- Berat & $8(20)$ \\
- Sangat berat & 0 \\
\hline
\end{tabular}

**Satu pasien bisa memiliki lebih dari satu defisit neurologis.

Tabel 3 menggambarkan bahwa 100\% subjek dengan gizi baik (9 orang) memiliki derajat keparahan tidak berat, sedangkan 43,8\% subjek dengan gizi buruk ( 7 orang) memiliki derajat keparahan berat.

Uji statistik menunjukkan hubungan yang bermakna antara luaran SGA dengan derajat keparahan stroke berdasarkan NIHSS (Tabel 3).

\section{PEMBAHASAN}

Berdasarkan hasil penelitian di atas diketahui bahwa karakteristik umum subjek penelitian sebagian besar adalah perempuan dengan frekuensi usia di atas 50 tahun. Penelitian sebelumnya di RSUP Dr. Hasan Sadikin, Bandung juga menunjukkan data yang sama. ${ }^{7}$ Hasil tersebut sesuai dengan penelitian yang dilakukan oleh Yetiana di Surakarta tahun 2013 yang melibatkan 80 pasien stroke sebesar 52,5\% adalah perempuan dengan usia rata-rata 45-81 tahun. Hal ini diduga karena perempuan lebih banyak mengalami obesitas dan memiliki riwayat hipertensi yang tinggi. ${ }^{12}$ Penelitian Zhan Wang di Cina tahun 2013 juga menunjukkan bahwa risiko stroke pada 
Tabel 3. Hubungan Derajat Keparahan dengan Luaran SGA $(n=40)$

\begin{tabular}{ccccc}
\hline & \multicolumn{2}{c}{ NIHSS } & & \\
\cline { 2 - 3 } Luaran SGA & Tidak Berat & Berat & \multirow{2}{*}{ Total } & p \\
\cline { 2 - 3 } & $\mathbf{n ~ ( \% )}$ & $\mathbf{n ~ ( \% )}$ & & \\
\hline SGA A & $9(100)$ & $0(0)$ & 9 & $0,008^{*}$ \\
SGA B & $14(93,3)$ & $1(6,7)$ & 15 & \\
SGA C & $9(56,2)$ & $7(43,8)$ & 16 & \\
Total & 32 & 8 & 40 & \\
\hline
\end{tabular}

*Fisher's exact test. NIHSS: National Institute of Health Stroke Scale; SGA: Subjective Global Assessment.

perempuan terkait frekuensi obesitas yang lebih tinggi dibandingkan laki-laki, karena hormon estrogen memengaruhi distribusi dan diferensiasi adiposit, sehingga sel lemak yang tidak normal dapat mengganggu status nutrisi dan meningkatkan risiko terjadinya stroke. ${ }^{13-14}$ Penelitian metaanalisis studi observasional oleh Michiel HF Poorthuis menunjukkan bahwa perempuan lebih berisiko mengalami stroke karena faktor hormonal dan terjadinya berbagai komplikasi kehamilan seperti preeklamsia. ${ }^{15}$

Penelitian ini menunjukkan bahwa hipertensi merupakan faktor risiko yang paling sering terjadi pada stroke. Didukung oleh penelitian Fang-I Hsieh di Taiwan dan Noortje Maaijwee di Belanda tahun 2014. ${ }^{16-17}$ Tekanan darah tinggi menyebabkan kerusakan sel endotel pembuluh darah, sehingga dapat memicu gangguan faktor pembekuan darah dan peningkatan reactive oxygen species (ROS) yang memengaruhi risiko terjadinya kerusakan serebrovaskular. ${ }^{18}$ Nutrisi juga berperan penting dalam mencegah terjadinya stroke, penelitian Lin PH di China 2013 menyatakan bahwa Dietary Approaches to Stop Hypertension (DASH) terbukti dapat menurunkan keparahan hipertensi ke arah stroke. ${ }^{19}$

Sebagian besar subjek penelitian mengalami stroke iskemik (60\%). Hal ini sesuai dengan penelitian Alyana A Samai di Amerika tahun 2015. ${ }^{20}$ Kejadian stroke berulang pada penelitian ini tinggi sebanyak 52,5\%, didukung oleh penelitian Daubail yang menunjukkan kejadian stroke berulang tinggi dan dapat bervariasi waktunya, yaitu setelah 1 bulan,
1 tahun atau 10 tahun setelah kejadian stroke akut. Stroke berulang erat kaitannya dengan kemungkinan derajat keparahan yang lebih buruk karena riwayat defisit neurologis pada stroke sebelumnya. ${ }^{21}$

Stroke dengan defisit neurologis dapat memengaruhi kondisi nutrisi serta derajat keparahannya. Defisit neurologis yang terdapat pada subjek penelitian ini adalah hemiplegia pada 38 orang, afasia pada 23 orang, disfagia pada 18 orang, penurunan kesadaran pada 17 orang, dan disartria pada 11 orang. Defisit neurologis tersebut menyebabkan penurunan kemandirian subjek untuk makan yang akan memengaruhi status gizi pasien stroke, sehingga kasus stroke yang dirawat di rumah sakit dengan kondisi malnutrisi sangat tinggi prevalensinya. ${ }^{22-23}$ Rute pemberian nutrisi ditentukan oleh kondisi pasien stroke. Pasien stroke dengan disfagia dan penurunan kesadaran akan memperoleh nutrisi enteral via nasogastric tube (NGT), sedangkan pada pasien dengan kondisi defisit neurologis lebih ringan asuhan nutrisi diberikan per-oral. Pada penelitian ini didapatkan $40 \%$ subjek mengalami gizi buruk (SGA C) berdasarkan penilaian SGA awal perawatan. Penelitian deskriptif di RSUP Dr. Hasan Sadikin, Bandung tahun 2014 menunjukkan hasil serupa. ${ }^{7}$ Hal ini menarik karena selama 4 tahun terakhir kondisi malnutrisi pada stroke tinggi, sehingga perlu mendapatkan perhatian lebih agar pasien memperoleh asuhan nutrisi yang tepat, dan diharapkan perbaikan nutrisi dapat meningkatkan luaran klinis.

Sebanyak $80 \%$ subjek memiliki derajat keparahan tidak berat. Pada penelitian ini hanya mengategorikan derajat keparahan berat dan tidak berat. Data yang didapatkan sebagian besar adalah defisit neurologis sedang yang masuk dalam kategori tidak berat, sehingga dominasi kategori tersebut diisi oleh defisit neurologis sedang. Hal ini sesuai dengan penelitian oleh Rega Dwi Wandira di RSUP Dr. Hasan Sadikin, Bandung tahun 2018, sebanyak 49 pasien $(60,5 \%)$ dari total 81 subjek penelitian memiliki derajat keparahan tidak berat. ${ }^{11}$

Penelitian ini menunjukkan terdapat hubungan antara luaran SGA dengan derajat keparahan stroke 
berdasarkan hasil NIHSS. Fereshteh Aliasghari pada penelitiannya mengenai hubungan malnutrisi menggunakan metode penilaian yang lain yaitu Mini Nutritional Assessment (MNA) dengan NIHSS tahun 2018 menunjukkan hasil yang signifikan. ${ }^{24}$ Hal tersebut disebabkan karena nutrisi berperan penting padaregenerasi selotak dan fungsifisiologisnya seperti hantaran impuls saraf dan hubungan antarneuron. Pada kondisi stroke didapatkan oxidative stress yang tinggi, hal ini akan memicu terjadinya kerusakan sel. Adanya antioksidan dapat berperan sebagai proteksi untuk mencegah kerusakan lebih lanjut. Antioksidan dapat diperoleh dari eksternal melalui asupan nutrisi yang baik. Protein dan mikronutrien dapat memengaruhi sintesis antioksidan sehingga kecukupan asupan protein dan mikronutrien yang baik dapat meningkatkan peran antioksidan. ${ }^{25-26}$ Pada status gizi pasien stroke yang buruk, makrodan mikronutrien tidak cukup untuk memperbaiki kondisi klinis stroke sehingga memengaruhi derajat keparahan. ${ }^{27-29}$

Keterbatasan penelitian ini adalah waktu penelitian yang singkat, waktu penilaian SGA dan NIHSS masing-masing pasien berbeda awitan strokenya, dan penilaian SGA hanya dilakukan pada awal masa perawatan sehingga kurang menggambarkan berbagai faktor risiko lain yang dapat memengaruhi status gizi dan luaran klinis stroke selama masa perawatan. Disarankan penelitian lebih lanjut dapat menilai faktor-faktor yang memengaruhi status gizi pasien stroke selama masa perawatan sehingga bisa mendapatkan masukan untuk perbaikan status gizi. Diharapkan dapat memperbaiki luaran klinis pasien stroke dengan waktu penelitian yang lebih lama.

\section{KESIMPULAN}

Terdapat hubungan yang bermakna antara luaran SGA dengan derajat keparahan stroke berdasarkan NIHSS.

\section{DAFTAR PUSTAKA}

1. Johnson W, Onuma O, Owolabi M, Sachdev S. Stroke: a global response is needed. Bull World Health Organ. 2016;94(9):634A-5A.

2. World Health Organization. WHO global health estimates; 2014. h. 1-13.
3. Kementerian Kesehatan, Datin. Kenali tanda-tanda serangan jantung dan stroke; 2014.

4. Paquereau J, Allart E, Romon M, Rousseaux M. The long-term nutritional status in stroke patients and its predictive factors. J Stroke Cerebrovasc Dis. 2014;23(6):1-6.

5. Mosselman MJ, Kruitwagen CLJJ, Schuurmans MJ, Hafsteinsdottir TB. Malnutrition and risk of malnutrition in patients with stroke: prevalence during hospital stay. J Neurosci Nurs. 2013;45(4):194-204.

6. Gomes F, Emery PW, Weekes E. Risk of malnutrition is an independent predictor of mortality, length of stay, and hospitalization. J Stroke Cerebrovasc Dis. 2015;25(4):799-806.

7. Kartika G, Amalia L, Nugraha GI. Nutritional status of hospitalized stroke patients: assessment by body mass index and subjective global assessment method. Althea Med J. 2017;4(2):293-8.

8. Lim SL, Lin XH, Daniels L. Seven-point subjective global assessment is more time sensitive than conventional subjective global assessment in detecting nutrition changes. J Parenteral and Enteral Nutr. 2016;40(7):966-72.

9. Kwah LK, Diong J. National institutes of health stroke scale (NIHSS). J Physiother. 2014;60(1):61.

10. Racosta JM, Guglielmo F Di, Klein FR, Riccio M, Giacomelli FM, Gonzalez E, dkk. Stroke severity score based on six signs and symptoms the $6 \mathrm{~S}$ score: a simple tool for assessing stroke severity and inhospital mortality. J Stroke. 2014;16(3):178-83.

11. Wandira RD, Amalia L, Fuadi I. Hubungan antara derajat keparahan stroke dengan kejadian strokeassociated pneumonia. Neurona. 2018;35(2):116-20.

12. Yetiana V. Hubungan antara status gizi dan mobilitas dengan risiko terjadinya dekubitus pada pasien stroke [tesis]. Surakarta: Universitas Muhammadiyah Surakarta; 2013.

13. Wang Z, Li J, Wang C, Yao X, Zhao X, Wang Y, dkk. Gender differences in 1-year clinical characteristics and outcomes after stroke: results from the China national stroke registry. PLoS One. 2013;8(2):1-9.

14. Gina LP, Annabelle VS. Burden of stroke in women. Trends Cardiovasc Med. 2016;26(1):81-8.

15. Poorthuis MH, Algra AM, Algra A, Kappelle LJ, Klijn CJ. Female- and male-specific risk factors for stroke a systematic review and meta-analysis. JAMA Neurol. 2017;74(1):75-81.

16. Hsieh F, Chiou H. Stroke: morbidity, risk factors, and care in Taiwan. J Stroke. 2014;16(2):59-64.

17. Maaijwee NA, Rutten-Jacobs LC, Schaapsmeerders P, Van-Dijk EJ, De-Leeuw FE. Ischaemic stroke in young adults: risk factors and long-term consequences. Nat Publ Gr. 2014;10(6):315-25. 
18. Rubattu S, Pagliaro B, Pierelli G, Santolamazza C. Pathogenesis of target organ damage in hypertension: role of mitochondrial oxidative stress. Int J Mol Sci. 2015;16(1):823-39.

19. Lin PH, Yeh WT, Svetkey LP, Chuang SY, Chang YC, Wang C, dkk. Dietary intakes consistent with the DASH dietary pattern reduce blood pressure increase with age and risk for stroke in a Chinese population. Clin Nutr. 2013;22(3):482-91.

20. Samai AA, Martin-Schild S. Sex differences in predictors of ischemic stroke: current perspectives. Vasc Health Risk Manag. 2015;11:427-36.

21. Daubail B, Giroud M, Be Y. Epidemiology of stroke and transient ischemic attacks: current knowledge and perspectives. Neuroepidemiology. 2016;172(1):5968.

22. Crary MA, Humphrey JL, Sambandam GCR, Miller L, Silliman S. Dysphagia, nutrition, and hydration in ischemic stroke patients at admission and discharge from acute care. Clin Nutr. 2013;28(1):69-76.

23. Nii M, Maeda K, Wakabayashi H. Nutritional improvement and energy intake are associated with functional recovery in patients after cerebrovascular disorders. J Stroke Cerebrovasc Dis. 2016;25(1):57-62.

24. Aliasghari F, Izadi A, Khalili M, Farhoudi M, Ahmadiyan S, Deljavan R. Impact of premorbid malnutrition and dysphagia on ischemic stroke outcome in elderly patients: a community-based study impact of premorbid malnutrition and dysphagia on ischemic stroke outcome in elderly patients: a communitybased study. J Am Coll Nutr. 2018;2018:1-9.

25. Rahal A, Kumar A, Singh V, Yadav B, Tiwari R, Chakraborty S, dkk. Oxidative stress, prooxidants, and antioxidants. Biomed J. 2014;2014:1-19.

26. Iversen PO, Ha L, Blomhoff R, Hauge T, Veierod MB. Baseline oxidative defense and survival after 5-7 years among elderly stroke patients at nutritional risk: follow-up of a randomized, nutritional intervention trial. Clin Nutr. 2015;34(4):5-8.

27. Tsai N, Chang Y, Huang C, Lin Y, Lin W, Cheng $\mathrm{B}$, dkk. Association between oxidative stress and outcome in different subtypes of acute ischemic stroke. Biomed J. 2014;2014:1-7.

28. Manuela A, Schieferdecker M, Eliana M, Neto C, Campos L, Carlos A, dkk. Nutritional status influences the length of stay and clinical outcomes in hospitalized patients in internal medicine wards. Nutr Clin Pract. 2013;28(4):1313-20.

29. Edwina JASN, Sri W, Tina NH. Tingkat perbedaan gizi status luaran dengan pasien klinis iskemik stroke. MNJ. 2017;3(1):17-22. 